\title{
Charlotte Lees Evans, 1841-1882
}

\author{
Anne D. Brown
}

Charlotte Evans is among the earliest of New Zealand's romantic novelists and a writer of popular romantic melodrama belonging to the 'Pioneer Period' of 1861-1889 in what is termed the 'sensation' genre (Jones 120). Evans was born in Lancashire, England on 21 September 1841 and died in New Zealand on 22 July 1882 at the age of 40 years. Evans' full collection of published works included three novels, of which the first, a story entitled Guy Eversley was serialised in the North Otago Times and Waitaki Reporter in 1865-66. This publication was then followed in 1874 by the two novels: Over the Hills and Far Away: A Story of New Zealand and A Strange Friendship: A Story of New Zealand. Evans also produced three short stories: A Narrow Escape, Only a Woman's Hair and Our Nearest Neighbour that were published posthumously in 1900 and 1903 by a London publication called The Family Herald. A selection of her poetry, also collected posthumously, were to be eventually published by her husband Eyre Evans in 1917. It is largely unknown, however, as to what extent Evans' novels were read, either in New Zealand or overseas. Copies of the first editions of her published works are now held in the National Library of New Zealand and Oamaru Public Library collections, along with a miscellaneous collection of prose and poetry entitled 'Fragments of Poetry and Prose' (ATLMS-Papers-4426). Evans' two major works, the novels Over the Hills and Far Away and $A$ Strange Friendship were both published in 1874, in hardback, by the international London-based firm Sampson Low, Marston, Low \& Searle. Sampson Low was one of the nineteenth-century's more prolific publishers of popular fiction that contributed significantly to the transnational world of Empire readership to which Evans belonged. Other writers published by Sampson Low included her contemporaries the American popular authors Harriet Beecher Stowe and Louisa May Alcott and the well-known British sensation writer Wilkie Collins. As versions of sensation narrative Evans' novels are recognised in The Oxford Companion to New Zealand Literature as being 'tightly plotted', incorporating recognisable 'sensation' features: i.e. 'crimes and secret past that 
helped separate hero and heroine' involving 'violations of Victorian sexual mores' (adultery bigamy, and illegitimacy) (Jones 125)). The elements recognised in sensation writing also featured an 'emphasis on the unravelling of a mystery that often turned on 'substitution and false identity)' (125). This also involved detective work and a 'documentary' method of telling the story', including 'partial perspectives of letters' (125). Prior to the full denouement of events would be a 'crucial pocket of time' accompanied by the 'effects of shock and surprise' (125). As a novelist, Evans' own reading would appear like many women of the Victorian period to have included the work of Charlotte Bronte, to whom she refers in the 'Preface' to Over the Hills and Far Away.

In terms of her biographical profile, Evans constitutes a degree of 'invisibility', having left little or no evidence behind in the form of extant diaries or correspondence. Without further biographical evidence, Evans' personality remains therefore somewhat obscure. Instead, like her novels, she can be viewed from a distance: firstly, as daughter and sister, wife and mother, and perhaps somewhat 'inadvertently' as published novelist. Evans is said to have had a 'committed Evangelical Anglican faith that shaped her life and her fiction' (Moffatt 19). Her religious faith was a facet of Evans' life well illustrated in the slim volume of posthumously published poetry entitled Poetic Gems of Sacred Thought. Her husband Eyre was an Irish protestant from Kilmallock, County Limerick. Like many 'gentleman' emigrants Eyre arrived first in New Zealand to take up farming which, in his case, lay in the district of Teaneraki or Enfield some miles distant from Oamaru township. Eyre was also a noted newspaper columnist on the subject of 'Temperance'.

Further insight into the life of the extended Evans family may be gleaned from extant Lees and Evans' correspondence; in particular the letters of Alice Lees Evans, the wife of Evans' elder brother James, whose early death in 1877 Evans is said to have felt keenly (Skillbeck Jottings of a Gentleman 88). More recently, the publication of Jottings of a Gentleman (1997) has provided valuable reference to Evans' years in Oamaru, using her husband Eyre's own words from his diaries and notebooks. These include private glimpses of Charlotte and her life in the early settlement frontier and its specifically shared values of mutual support. A consideration of Evans' personality and literary 
works thus incorporates her social milieu and domicile of Oamaru, its burgeoning print culture and her own network of kinship.

\section{The Lees of Lancashire}

Evans emigrated to New Zealand in 1864 and came from a middle-class family. Her parents James and Sophia Lees (nee Ball) had four children, two boys and two girls, of whom Charlotte was youngest. A descendant writes that the Evans children were gifted and well educated, each of them displaying individually a love for painting, music, inventing and for Evans particularly, a natural propensity for trying her hand at poetry and stories (ATL-MS-Papers13-19-1). The Lees family appear to have been close-knit, with a tradition of having had affectionate nicknames dating back to the mid-1700's (Skillbeck 65). The Lees originated from Clarkesfield, an area situated in the district of Oldham, an industrialising area of Lancashire in the north of England where James Lees owned a 'sizeable' cotton mill (65). James disliked the trend in slave labour, however, and in the early 1860's sold his business to move further south to Devon where the family lived in the vicinity of Richmond and East Dean (ATLMS Papers -13-19-1). Evans spent the memorable times of her later girlhood there, enjoying 'a number of short holidays and staying with friends and relations in places such as 'Windsor, Plymouth, Bath, Dawlish, Brighton and even Paris' (ATL-MS-Papers-13-19-1). She thus became familiar with some of the better known landmarks of Devon and Sussex, in particular Plymouth and Dawlish Bay, both of which are mentioned in her novel Over the Hills and Far Away.

In 1864 Charlotte's parents decided to emigrate to New Zealand. James Lees' plan was to invest in land out in the colonies in the belief that 'farming would be the basis of New Zealand's future prosperity' (Skillbeck 65). He was by then 59 years of age. The Lees' two sons Joseph and James had already travelled out ahead of them to settle in Otago. In July of 1864 the remaining family of James

Snr, his wife Sophia and younger daughter Charlotte, then set sail from England on the passenger ship 'Chile', arriving safely in the South Island of New Zealand at Port Chalmers on 17 November (64). 
Having recently left the chilly winter of the northern hemisphere the Lees' first experience of life in New Zealand took place over the months of early summer. With capital to invest James and his sons had already been engaged in purchasing property at 'Teaneraki', an area of land located several miles out of Oamaru's township and situated 'in a beautiful valley sheltered between ranges of hills and watered by the Waiareka Creek' (See Appendix I) (69)). The Lees' stationhome 'Teaneraki House' was among the adjoining properties belonging to 'Teaneraki Estate' which comprised the Lees family estate and its network of relations. These included Charlotte's cousin Edward who lived at 'Matapuna' - a station-home 'easily visible to the north of 'Teaneraki House' (64). Charlotte's two brothers also settled at Teaneraki, namely Joseph, married to Edith Frost and James who married his cousin Alice Lees and settled at 'Alverton' (ATL MS5135-09). Later, Charlotte and her husband Eyre Evans went to live on a property belonging to Teaneraki Estate called 'Friston'. The Lees were also joined in New Zealand by their eldest daughter Sophia who had married Charles Gifford-Moore in Cornwall in 1858 (Skillbeck 64). The experience the Lees had in the cotton industry appears to have fitted them well for establishing another enterprise in the Oamaru district under the name 'Lees-Moore', which was a flour milling business owned jointly in partnership with Gifford-Moore (who was by then resident in Oamaru (See Appendix I)). Gifford-Moore became prominent also as the District Engineer and Surveyor for Oamaru, while Evans' elder brother James gained influence as an inventor of barbed wire fencing which he then developed into a local business (89). Family enterprise contributed to the district's progress well into the late 1870's, as the Mill, followed by the building of a school and railway, was said to have owed much to the Lees' family's 'generous planning and action' (67).

The Lees' emigration to the colony was intricately linked with that of two other kinship influences; notably the Evans' of Ireland and the Ogilvie-Grants of Scotland (ATL-MS-Papers13-19-1). Both the Evans and Ogilvie-Grants represented a connection with landed gentry and aristocratic title significant to Evans' novel A Strange Friendship and that of earlier departure by an advance party found in Over the Hills and Far Away; an emigration pattern more immediately attributable to Charlotte's future husband Eyre Evans. Born Eyre 
Fitzgeorge Evans on 23 February 1842, Eyre was of Irish landed gentry stock, the eldest son of four children of Major George Evans by Louisa Barbara (nee Corry) (Skillbeck 6). His grandfather Eyre, after whom he had been named, had been an 'Irish Country Squire' whose home 'Ash Hill Towers' was situated in County Limerick (2). The Evans held title to the Baronet of Carbery (2). On Eyre's maternal grandmother's side he was related to the 'Halls' of Newry in County Down whose stately home 'Narrow Water' Eyre spent holidays at during his youth (see Appendix I) (9). Not being heir to the Carbery family title, Eyre's father George had instead gone into the military, and as a training cadet at Sandhurst Military Academy in 1826, been a contemporary of New Zealand's future Governor Sir George Grey. Eyre's growing up years were spent in the town of Newry. He was educated at the Royal School Dungannon in County Tyrone before attending Trinity College, Dublin (8).

It was at Trinity College that Eyre met Charles Gifford-Moore (20) and made the acquaintance of James Lees, Charlotte's father (26). As the Lees' sons were already planning to leave for New Zealand 'life in the colonies' soon became a 'constant topic of conversation' (26). The enthusiasm of that meeting, and the plans that followed, initiated a pattern of colonial 'diaspora' which eventually reunited the two families again in South Otago where the Lees had purchased property at 'Teaneraki'. The 'advance party' thus took the form of the Lees brothers Joseph and James both travelling out to New Zealand aboard the 'Motueka' from Gravesend in 1863 (64). They were followed, in 1866, by Eyre and his younger brother Trevor Corry sailing ahead of their parents and other siblings aboard 'The Queen Bee' (28). On the journey out, the brothers 'pretended to be sailors themselves', while Eyre wrote and sketched a record of the shipboard life he experienced in a travel diary (see Appendix I). Upon disembarkation at Port Chalmers his first impressions featured the same rolling Otago terrain frequently referred to by Evans in Over the Hills (55).

In her role as wife and mother at Friston Evans herself remains rather less visible. More than certainly, the demands of domesticity had spoken for a great deal of her time, being ostensibly similar in many of its aspects to the lives of those families mentioned in her novels (i.e. the Somersets in Over the Hills and Far Away and the Cunninghams of $A$ Strange Friendship). Evidence of 
Charlotte's domestic life can be found again in Eyre's own recollections, in which she was remembered as being 'much occupied' with caring for children and domestic matters (Skillbeck 77). Eyre's later memoirs occasionally recount rare insights into their experiences. A conscientious man, Eyre had tried his 'very best to learn and manage the estate' while his 'beloved Charlotte ran as comfortable and well-ordered a household as could be in our circumstances' (76). The earlier times in the couple's marriage had been prosperous enough to have allowed 'some help around the house' - a dispensation making them 'among the more fortunate' of local settlers (76). The shared life of the settler families, set amidst the primitivism of the frontier landscape and early township of Oamaru, also included social evenings that were enhanced by what Eyre remembered later as a mutual 'appreciation of the arts and a lively sense of humour' (77). On visits to Oamaru and at Friston, Evans spent time with her relations, enjoying informal entertainments in the Victorian manner, with Gifford Moore and Eyre both taking turns at singing and recitations (77). It was in the quiet evenings at Friston, however, following a day's domestic activity, that Evans did much of her creative written work. Eyre remembered how Evans 'continued to write ... not only because it was something she loved to do, but also in the hope of earning some extra pennies to supplement our meagre income' (78). In a 'portrait' of the pioneer novelist at work Eyre saw his wife with 'head bent over the paper on which she was writing', while 'the glow of the candle would light her page' (78). During these evening hours Evans also sketched her short stories, in addition to the novels that were later published in 1874 , with the more serious intent of eventual publication in mind.

The deaths of three of their children, though mourned deeply, were met with a certain stoicism as the imperatives of pioneer existence again ruled Eyre's feelings ('death in infancy was such an occurrence then, but we, like others, tucked the personal heartache into our memories and got on with life') (81)). The couple's private grief was evident again in Eyre's diary entry that reads: 'On 28 January 1873 our little Alice left us before we had time to know her. I purchased a plot in the general cemetery for two guineas' (81). Alice's name also appeared on the dedication page for $A$ Strange Friendship. In another, more happy domestic anecdote, Evans was remembered writing to her 
daughters staying in Oamaru to tell them about Percy's pet sparrows (76).

Evans was also religiously minded. Of the two, wrote Eyre: 'Charlotte in particular seemed to draw great strength from her Christian faith', expressing 'the sincerity of her feelings in her poems and hymns' (75). The same sense of religious piety was reflected again in her religious poems or 'Sacred Verse'. Both Charlotte and Eyre contributed enthusiastically to local spiritual fellowship, with 'faith and Christian company' being an indispensable element in the lives of the early colonists (75). Church news and reports of meetings supported feelings of solidarity with an accompanying sense of 'do unto others' as well as a spontaneity (75). The properties belonging to Teaneraki Estate were situated some miles out of Oamaru. This meant that Sunday meetings habitually took the form of services read 'at the farm' at which the men gave sermons. Evans also took her turn with occasional preaching. The overall effect gave an individual, even 'evangelical', feeling. At 'Cloon Eavin' a wooden chapel 'Bethel' had also been built. Eyre's sister Nina married Frank Ogilvie-Grant there on November $24^{\text {th }}, 1874(76)$.

\section{The Writing Years}

Throughout the Friston years writing became for Evans not only a source of private enjoyment but also an increasingly professional activity. The correspondence with her publisher, Sampson Low, and the reviews that followed, created their own excitement among her immediate circle at Teaneraki. From 1874, Evans might have written with even greater purpose, yet it appears that much of her writing was by then completed. Upon publication, Evans was pleased 'that her stories set largely in the New Zealand landscape had 'appealed to her fellow colonial readers as well as those in England' (Skillbeck 79). Reaction to Evans' writing successes within the Lees circle was also unanimously supportive. The publication of Over the Hills and Far Away in hardback by Sampson Low and its arrival at Friston, with the inscription 'to my husband', was a surprise for Eyre (78). Shortly after Sampson Low's commissioning another story, Alice Lees wrote home to England that 'Carolo was bringing out a story in one of the English magazines', urging them to 
'please buy the book A Strange Friendship: A Story of New Zealand Life (ATLMS-Papers-5135-09). Evans' relatives at Teaneraki responded again to a critical review that appeared in the Otago Guardian on [26 October]:1874:

A family and local 'legend' connection with ancestral title known as the 'Seafield Inheritance', or 'Earldom of Seafield', also constituted yet another point of reference for Evans, the 'romance novelist' (Skillbeck 93). 'The Seafield Inheritance' was unique in its New Zealand context, providing a link between Britain and colony that surpassed Evans' lifetime yet in the breadth of its saga continued its grip on family mythology. Frank Ogilvie-Grant's accession to the title 'Viscount Reidhaven' whilst still resident in Oamaru, was not fully realised until 1884, two years after her death in 1882 (93). At the same time, Evans' novelistic imagination of Empire romance also absorbed the ancestral heritage of her in-laws Major George Evans and Louisa Corry, who were by then living at 'Cloon Eavin' (69). Her husband Eyre looked to 'Ash Hill Towers' - the place where he had been born and where his father George had grown up. There was also 'Narrow Water Castle' in Newry, County Down - the ancestral seat of the Halls (9). Working from her colonial sitting room at Friston, Evans may have found something of her own 'escapist' fulfilment in writing these same themes of ancestral ties - always somehow beyond reach - into her story plots, such as that of Alan Ainsleigh's inheriting of 'Curtis Knowle Estate' in A Strange Friendship. The other side of Evans' inner life dwelt also on the prospects of human relationship. At the borders of her imagining during the years at Friston, was the mutually interdependent nature of men and women in their social relationships in the colony. This had meant for women a cultivated subservience to an economic order of frontier survivalism and inherited custom. Although, at least on the surface, those in her immediate circle possessed a compatible 'gentility', Evans engaged with more archetypal feelings. Heavily dependent herself upon her men for economic support and social identity she dreamed of their opposite.

Changes in her family circle continued to affect Evans' last years. There had been the deaths of three children and now the demands of her domestic life were, if anything, more pressing. She missed her sister Sophia who had died in the early ' 70 s. In 1877 her friend and sister-in-law Alice Lees had died suddenly 
on the return to England only a day before arriving at Liverpool (88). Upon returning to England, Evans' other sister-in-law Edith also died, leaving her brother Joseph with a large family of 16. By the late 1870's Evans was relatively bereft of those with whom she had first emigrated to New Zealand back in 1864. Evans' pregnancies continued with the birth of six more children: George in 1877; Savage ('Toss') in 1878; Robert in 1879; 'little' Eva in 1880; and James in 1881. On 22 July in the winter of 1882, soon after the birth of their last child Eric on 16 July Evans died - suddenly - of 'childbirth' fever. This left Eyre with a family of nine to support aged between 6 days and 13 years (87). A brief notice marking Evans' death was recorded in the North Otago Times on 24 July 1882. At that time the family were situated at Eden Street. She was buried close by her other relatives in Oamaru Cemetery. No obituary was published. She was recorded as 'Charlotte, the beloved wife of Eyre Evans, aged 40 years' (ATLMS-Papers-5135-09). Although he was to marry again, having another son Thomas Charles in 1890 with his second wife Mary, Eyre's remembrance of Evans as companion wife, helpmate and writer/novelist maintained its hold (99). More urgently, it was his sister 'Aunt Nina' Ogilvie-Grant, who came to his assistance as governess and helper in the months leading into 1883. To 'try to make the best of things' Eyre then moved the family into a smaller residence in Eden Street (Skillbeck 93).

\section{The Family Herald}

Eyre's later years were characterised by a period of travel and more active journalism. A committed Christian socialist, Eyre had been a contributor to the North Otago Times (246). Over the years he kept a series of notebooks entitled 'Stray Thoughts', in addition to a number of scrapbooks, filled with newspaper cuttings and articles he had published over the years on 'Temperance' (61). As the colonial newspapers, including the North Otago Times, led public discussion on the all-important topic of the social problems of unemployment and drinking, Eyre too had joined those speaking out on the subject (246). On visits back to England in the 1900s he attended lectures and wrote articles for British newspapers, among which was The West End Press [ATL-MSX-Papers-3945]. The name 'Charlotte' continued to be mentioned from time to time, most 
noticeably in connection with The Family Herald (JOG 197). In a scenario suggestive even of Evans' own sensation novel, the story concerning posthumous publication of her short stories began with a letter; one published by Eyre in a London paper, which led him in turn to a relative living in Richmond (197). Eyre was there enlightened to the fact that Evans' stories were about to be re-printed in The Family Herald, her former publisher. He recognised a story that looked remarkably similar to one he had helped his wife revise some time earlier entitled 'Our Nearest Neighbour' (197). A protracted correspondence followed with the editor of The Family Herald; the first letter dated $15^{\text {th }}$ July 1903 launching an inquiry over copyright that took some months and considerable 'chance' to negotiate satisfactorily (198). Evans had formerly received a five pound payment for each of the stories: Only a Woman's Hair, $A$ Narrow Escape and Our Nearest Neighbour. After repeatedly requesting that all three be accounted for, Eyre managed to locate Our Nearest Neighbour as being No. 121 on the list of a series produced by The Family Herald called 'Happy Hour'. The Family Herald eventually agreed to a full settlement (200). In a final recapitulation of the mysterious 'clue' familiar to Evans' sensation writing, there was to be yet a further denouement. Eyre then received a final letter from the 'Herald' disclosing that the stories had in fact previously appeared in a 'Magazine of Fiction' series which, however, was 'not likely to be republished' (200).

After 1882 Eyre recorded that he hoped to one day publish Charlotte's poems. This aim was to be affected by the Great War of 1914-1918 in which their sons, like others in the district, inevitably became involved (245). Four of the children, including 'Tom' from Eyre's second marriage, served in the Gallipoli and Boer campaigns, while Percy and Eric remained stationed in New Zealand. Tragically another son, James, was killed in action while serving in France in September 1916 (244). Having found solace in Evans' words during these war years Eyre finally brought out a local edition of her selected poems, under the title Poetic Gems of Sacred Thought which was printed and published by J.H. Cunningham and Son of Wear Street, Oamaru (245). Those of Charlotte's children to marry included Ethel, who in 1890 married Robert Milligan, a businessman and later Oamaru Mayor (99). Eldest son Percy was at one time on the staff of the North 
Otago Times, while Eric, practising in the pastoral ministry, followed his parents' Christian beliefs and served during the war years as army chaplain (245). Kathleen ('Kitty'), however, died young at 22 years while living in England (100). On the 22 August, 1919 Eyre died aged 77 years. An obituary was given in the Oamaru Mail the following day on 23 August (248). Of all Charlotte and Eyre's seven surviving children only Thomas Charles, the son of his second marriage, continued the Evans' name in Oamaru into the $20^{\text {th }}$ century. The saga of the three closely interlinked colonist families was to disperse somewhat over the next hundred years, with descendants of Eyre and Charlotte's marriage being situated mainly between England and Australia (ATL-MS-Papers-13-19-1). In this way the family name carried on the theme of diaspora between nations and continents, Europe and the antipodes, also synonymous with Evans' 'Early Pioneer Period' writing.

The story of Evans' writing was characterised by an overall creativity that was quietly celebrated, yet lacking a clear chronological pattern. This was in part due to a lack of evidence surrounding the first publication dates for Evans' stories. Family correspondence and diaries surrounding Evans' publications indicate that writing was seen as a means toward livelihood (Skillbeck 78). Except for a short period of time when Evans reportedly worked on the staff of a 'leading periodical' in the late 1870's, there is no indication of her having produced any significant pieces of writing after 1874 (87). Prior to 1874, the year of her novels being published, Evans had been in association with a London periodical The Family Herald (78). Following the publication of 'Guy Eversley' in the North Otago Times between 1865-66, it appears that Evans would around that time have been mainly preoccuppied with The Family Herald - cited as a 'domestic magazine of useful information and amusement' (78). The short stories: Only a Woman's Hair, A Narrow Escape and Our Nearest Neighbour were later found to have initially appeared in the 'Herald's 'Happy Hour' series between 1866-1874 (either 'as short stories or in serialised form') (78). Evans' novels also had a preliminary association with The Family Herald, with Over the Hills having been first submitted as a draft for a short story before it was discovered by Sampson Low. The firm then wrote to Evans with the suggestion that the story be re-written as a novel, offering her an advance of 
twelve pounds (78). The news of this success brought forth an enthusiastic response from Alice Lees, while Evans wrote the following:

Evans then received another letter from Sampson Low with the suggestion for a second novel (78). The next book, entitled A Strange Friendship, for which she received the same payment of twelve pounds, came out later in 1874 published jointly by a New Zealand firm Reith Wilkie of Dunedin (78). Reviews soon followed in the North Otago Times and Otago Guardian. During this period it is likely that Evans was more than usually occupied in providing the additional chapters for Over the Hills and writing her second novel. In 1874 the publication of Over the Hills and Far Away and A Strange Friendship secured her local reputation as a colonial novelist. The posthumous phase in Evans' writing career did not occur until after Eyre had obtained rights to re-publication of the short stories in 1903 under the title Only a Woman's Hair. Two of the stories in the collection of three novellas i.e. A Narrow Escape and Our Nearest Neighbour had already come out in The Family Herald Press some years previously in 1900. These events at least served to restore copyright ownership again under Evans' name. In 1917 a selection of Evans' poetry, representing a more directly personal aspect of her writing, was published by the New Zealand firm J.H. Cunningham and Son as Poetic Gems of Sacred Thought (245).

The reception to Evans' work in local reviews - such as those which appeared in the North Otago Times and Otago Guardian - was in general favourable. Reviews in local papers expressed support also for the development of a 'colonial literary industry' of which Evans was seen as representative (ATL-MSPapers-5135-09). The critics, including J.G. Flatt, drew attention to the novels as products of popular romance and as 'stories of New Zealand' with a flavour of the colonial that seemed somewhat unusual to contemplate (ATL-MSPapers-5135-09). Thus the reviews reflected the primarily Empire-driven period of 'Maoriland' fiction (1872-1914), viewing Evans' saccharine and picaresque narratives as 'pretty descriptive passages ... honed with the hand of an artist who evidently loves her task' (ATL-MS-Papers-5135-09)). While critics observed that in neither work did Evans' story 'hinge upon any peculiar phase of colonial life', her New Zealand-based characters earned attention nonetheless as the 'creatures of her fancy' that were made 'thorough colonists' (ATL-MS-Papers- 
5135-09). A review dated as early as February 1874 did, however, arouse speculation as to the actual order of publication for the novels (MS-Papers5135-09: MSX-3976).

Of the novels Over the Hills received two reviews by local newspaper critics; one singly and the other in conjunction with A Strange Friendship - both in 1874 (ATL-MS-Papers-5135-09). The North Otago Times also featured a lengthy review for $A$ Strange Friendship (see Appendix I). A shorter review for $A$ Strange Friendship appeared in the Otago Guardian on October 26th. Critics attended to plot and narrative style and considered Over the Hills to be 'well and gracefully told'. The plot of $A$ Strange Friendship's was thought by an (unnamed) reviewer as the more 'cleverly conceived', while Over the Hills was considered 'somewhat sketchy and without complication of by-plot' (North Otago Times [February]: 1874). Critics also noted Evans' skill in managing her storylines, in particular that of $A$ Strange Friendship being effectively 'maintained to the end'. A Strange Friendship also received praise for its swiftness of plot and economy of style that eliminated the need for readers to skip 'tedious parts' in the story (ATL-MS-Papers-5135-09). Critics responded to the 'improbable' as it related to both works. The circumstances surrounding the novel's arch villain, Richard Carewe's introduction to the plot in A Strange Friendship was questioned, and his dubious and criminal character cited as 'unfortunately real enough'. An insightful and descriptive review of $A$ Strange Friendship did, however, appear in a more perusing look by a North Otago Times critic, who offered the opinion that a 'local paper' had been 'strongly condemning' of Evans' second novel. Reviews previously read in the London Times, on the other hand, had been congratulating to the 'authoress on a genuine success' (North Otago Times 1874).

\section{Novelist of the 'Romantic Frontier'}

Evans was among the earliest of colonial authors to contribute a version of popular romance literature that was both situated in the 'exotic' and set in New Zealand. The colonising world that Evans herself daily inhabited represented a changing social milieu which inevitably coloured her work. In the process of departing from what could be described as autobiographical to venture into the 
realm of the improbable, or sensational, Evans incorporated features belonging to the contemporary 'sensation' novel that was then becoming popularised by Wilkie Collins (Jones 125). Her works were an earlier version of the colonial novel based on settler culture that could be termed a 'domestic hybrid of romance and realism' (Shires 61). Evans' work also conformed, at least to some degree, to the Oxford History of New Zealand Literature in English's 'primary modes of the Pioneer novel' i.e. 'naïve realism', 'exploitive conventionalism' and 'didacticism' (122). In the first instance of 'naïve realism' (122), unlike those pioneer novels representing 'a fictional extension of the non-fictional 'literature of occupation' (122), Evans' work was focussed strongly within the conventions of popular romance narrative, while her characters were situated as colonists with assumed 'biases and values' (122). In terms of 'exploitive conventionalism' (122), Evans' melodramatic plots relying on conventional family patterns of a colonising society and set in New Zealand, reflect Jones' 'pioneer pattern of appropriation' involving New Zealand materials within an 'existing conventional formulae' (122); thirdly in terms of 'didacticism' (122), Evans' use of a 'moral message' as a narratorial device is also seen to parallel Jones' 'use of New Zealand materials' in fictions for which 'a moral, religious, or political message' is relevant (122). The genre in which Evans wrote has been cited as controversial and at the centre of a debate that questioned the role of the popular novel in a 'rapidly changing society' (David 1). In the cause of a romance writing that incorporated elements of the gothic, Evans employed a Victorian 'domestic realism' or domestic style in the placing and description of her characters and colonial sitting rooms - for which 'chintz sofas' and 'paisley piano shawls' (David 2) combined with 'pianos, croquet and the drinking of claret' (Robinson 169) .

As works of the early pioneer period, Evans' novels and short stories also conformed to the Maoriland era in transtasman publishing that marginalised or appropriated the 'indigenous' (Stafford and Williams). Evans' Empire style romance blended with a saccharine frontier landscape that, in its undulating hill tussock and mountain scenery might, as her critics have suggested, been in Britain if it weren't for the convenient mention of a Maori placename or 'native' flora and fauna. Yet as viewed by contemporary critics, and seen in their own 
time period of 'Maoriland' writing, Evans' novels in particular appear to have met the needs of Empire readers and critics alike as forms of colonial literature (Stafford and Williams, Introduction: A Land Mild and Bold 1). In serving the aims of escapism Evans provided her own milieu of New Zealand as the convenient setting; a place wherein the mainly 'respectable' dissident or disaffected character could resolve their past dilemmas, and a place over which disenchanted heroes and whimsical heroines of leisure could deliberate with ennui and nostalgia. In her role as a romance writer, Evans managed to infiltrate these scenes with aliveness, candour and flashes of mockery and irony.

Seen as a reflection of the Victorian middle-class pattern (Pykett 1) Evans'own family circle at Teaneraki, from which she took inspiration, could also adapt to a form of 'sensation' writing that identified criminal or deviant behaviour within a veneer of social respectability. By 1874 this aspect of the sensation novel had already aroused concern among local newspaper critics (North Otago Times [October 15] 1874). Peopled by a society of conventional tastes and social ambitions, Evans' works explored a world of manners surrounding the propertied classes, while at the same time they exploited the sentimental and melodramatic qualities of popular romance. This included the indispensable elements or rituals of marriage and courtship. Her characters were English colonists, arriving to settle in the Canterbury region of South Otago, in what might be termed a version of the English rural 'gentry' (Arnold 159). Central to the characters' thoughts was the task of establishing a new home in New Zealand that involved the setting up of a 'homestead' or station home (see Appendix I) - and even more significantly - of becoming suitably acquainted with neighbours. In Evans' fictional versions of colonial life however, these perceivably laudable and realisable aims were soon to become subject to 'other' or unexpected influences. Of paramount significance to the (mainly women) consumers of Evans' brand of Empire romance was thus the consequence, of a social and moral non-conformism, that could then be 'safely' negotiated in a geographic location remote yet enticingly similar.

The relative homogeneity of Evans' characters contrasted with the 'other' in 'stock' characters from early pioneer novels, such as Farjeon's working class 'Grif' (Jones 121). In contrast to 'Grif', who must seek his identity at the 
periphery of a landowning, or relatively affluent middle-class, Evans' characters become subversive by their own volition. Evans used the sensation elements of crime, mistaken identity and sexual misalliance to disrupt the conventional expectations of her colonists, and thus also reverse what would be considered normative in the 'functioning' Victorian family of the 'respectable classes' (David 97). Evans represented what was then normative in dress, custom and social decorum via masculine and feminine stereotypes, while also allowing for hints of patriarchal dominance to intrude among her family portraits; (as seen in the outbursts of temper by Lucy's father in Over the Hills (OHFA 95)). In Evans' novels men were dissolute and 'cavalier' or hardworking and resilient. Women, on the other hand, were staged as decorously aloof or 'plain' and virtuously homely. According to romance convention Evans' hero and heroines also underwent trial by ordeal and spiritual suffering before they could be satisfactorily united, either on earth, or in the case of Lucy and Dacre in Over the Hills, in a union of 'eternal' fidelity (Chapter 33). In addition, Evans' faith in the reformation of her characters' dispositions and fortunes formed a pattern of resolution that was recognisable elsewhere among the generality of her published and unpublished work.

\section{Contemporary Women Novelists}

An increase of interest in New Zealand novels has more recently enabled Evans to be viewed in context with other women writers of the period as defined in The Oxford History of New Zealand Literature as 'Early Colonial' 1861-1889 and 'Late Colonial' 1890-1934 (Jones 134). Although Evans managed to achieve publication with the international publisher Sampson Low, Marston, Low \& Searle, her mainly intermittent writing career and domestic position likens her also somewhat to those 'amateurs' defined by Jones, who wrote and produced fiction that was 'at best an occasional avocation in the midst of lives dedicated primarily to the more material concerns of a pioneer society' (Jones 121).

Among Evans' women writer contemporaries is the well-known pioneer novelist and diarist Lady Mary Anne Barker whose works Station Life in New Zealand (1870) and Station Amusements in New Zealand (1873) (NZETC Collection) are now classics. Other pioneer period women novelists include the following:- 
Isabella J. Aylmer: Distant Homes: Or the Graham Family in New Zealand (1872 ) (NZETC); Emilia Marryat Norris: Amongst the Maoris: A Book of Adventure; Elizabeth Boyd-Bayley: A New Zealand Courtship and Other WorkA-Day Stories and Clara Cheeseman: A Rolling Stone Vols I-III (1886) (NZETC). Other women authors represented during the latter half of the , or 'Late Colonial Period' were Jessie Weston: Ko Méri, or, A Cycle of Cathay: A Story of New Zealand Life (1890); Eleanor C. Price: Mrs Lancaster's Rival; Louisa A. Baker: Wheat in the Ear (1898) and Edith Searle Grossman (NZETC). Along with other 'Early Pioneer' period novelists Evans' novels in particular focus on early rural settlement themes, with a marked vindication of the stabilising effects of marriage, courtship and property acquisition. This conservative optimism of Evans' was markedly in contrast with later developments in the New Zealand novel, such as the more psychologically and self-determining themes characteristic of Grossman and Baker's urban novels of the 'Late Colonial' era (Jones 135). Instead, Evans works more closely within the confines of popular 'escapist' romance; maintaining her focus on the tightly woven sensation plot (Jones 125). Cheeseman and Norris, for example, weave their story lines in the more leisured style and tone of the popular easy to read epic. It is in these earliest examples of the New Zealand novel, that local scenery and people were exposed for the first time to an 'unknowing' Empire readership. In their deployment of imagery and metaphor, Cheeseman and Norris enjoined with Evans at least to some extent, suggesting a yearning for the familiar amidst suggestions of the strange and uncanny. Along with Isabella Aylmer, another pioneer woman novelist of the 1870's, Cheeseman and Norris shared Evans' concern with the values and perceptions of English immigration and settlement in the rural frontier, set against an exotic backdrop of the indigenous and a peopled landscape of 'natives' or 'savages'. Corresponding perhaps even more directly with Evans' style as a popular romance novelist, were the 'escapist' qualities to be found in Aylmers emigration tale of Distant Homes: Or the Graham Family in New Zealand.

\section{Pioneer Writer}

For Evans, writing in isolation was a pervasive dream. In Our Nearest 
Neighbour she wrote of the change of moving from 'a very social town' in England (1). During the years at Friston between 1867-1877 when most of her work was achieved, what was 'nearest' were then her own relatives; the in-laws settling into their homes on Tenaereaki Estate and even more evocatively, the saga of the Ogilvie-Grants and the Seafield Inheritance. Evans' evening hours spent at candlelight constituted an exercise of the literary sensibility, filling the gaps for more regular or wider reading habits. Inspiring her imagination was her own circle of relatives and their emigrations from more established or illustrious surroundings, such as the Evans' ancestral homes in Ireland. In their place were the realities of colonial station life presenting a new realm of 'frontier' romance. As a pioneer author Evans wrote on the periphery of the domestic, yet with the support of her husband and kin. Surrounding them were the hills of South Otago. It was a different and a separate life from that which they had previously known. In terms of the world of transtasman publishing, the novels, short stories and poetry Evans wrote between 1867 and 1882 constituted an initial attempt, in the form of romantic melodrama, at a conceptualisation of the frontier for which the natural forms and sensations of New Zealand life formed a 'backdrop'.

The $20^{\text {th }}$ century New Zealand novelist Janet Frame also shared Evans' former domicile of Oamaru, having moved there in 1931 at the age of 7 years with her family (King 25). In Toward the Is-Land Frame retraces her ancestors from Scotland and the Jersey Isles, seeing them as 'myth and reality' (7). Among her relatives (who like Evans had emigrated to New Zealand in the nineteenthcentury) was a poetess, also named 'Charlotte', to whom Frame was related on her mother Lottie's side. Named 'Charlotte Nash' Frame's grandmother was the author of a collection of poetry published in a 'small book with an engraved cover' (8). According to Frame's recollection the poems had been 'written at eighteen before her [Charlotte Nash's] emigration from Harbledown, Kent, to New Zealand' (8).

Like the Evans at Friston, Frame shared with her parents and siblings a passion for 'poetry and reading, writing, and reciting it' (9). During childhood she read works by early American novelists (contemporaries of Evans) such as Harriet Beecher Stowe and Henry Wadsworth Longfellow. Frame's mother Lottie was 
an amateur poet, contributing to the poetry section of the 'Wyndham Farmer' (20). Living in the 1920's at the farther reaches of Evans' 'Empire' New Zealand, Frame had shared similar impressions: a visit by the Prince of Wales to Dunedin and occurrences of natural disaster in the flooding of St Kilda. The Eden Street of Frame's early Oamaru years provoked vivid sensations of a new house and neighbourhood that was both a symptom of agedness, yet a 'treasure of new experiences'; of 'climbable' places, including a 'summer house' (which then became a 'playhouse and theatre' (31). At the top of a hill in Frame's Oamaru were 'caves and fossilised shells' - the reminders of a buried past. By then, the town with its old 'stone buildings' and dilapidated quarter sometimes seemed a 'ghost city', yet a place nonetheless exciting in its rituals with a clock that chimed 'every quarter hour' (32). Frame's relationship as a school Dux medal subscriber with the forerunners of the 'Oamaru's Athenaeum and Mechanics Institute' had symbolised too the latter end of a spectrum in Oamaru's development as a town with some pretension to Victorian grandeur. Then established as a public lending library, with a ground floor museum, 'The Athenaeum' appeared, like the hill of caves, as a form of extinct memory and hushed quiet (70). On the level above the museum ('feeling in awe of the world of books in a library') Frame extended her reading experiences in the Juvenile section. Her reading at that time included her sister Myrtle's True Confessions and True Romances (71).

Representing an earlier and formative phase in Oamaru's history Evans has since earned her unique place as a settler author well situated in her locale. Writing for her 'romance' audience, Evans formulated fresh vistas by drawing upon the life at Teaneraki. In the Alexander Turnbull Library, a few sheets of faded parchment now symbolise the isolation of that existence from the main centres of cultural Europe to which Evans refers in her 'Preface' for Over the Hills (ATL-MS 13-19-1). Reviews published of her writing (i.e. the novels) clearly saw Evans in pioneer terms, as a writer of fiction, and as a welcomed authoress, willing to transcribe the experience of European settlement in the colony. In her relatively brief lifetime, Evans was however unable to encompass fully the movements within her own circle, including that of the Ogilvie-Grants and the Seafield Inheritance - all of which had encapsulated for her more 
personally the spirit of romance across the seas, between colony and 'homeland'. As a writer of the early to mid-Victorian period, Evans epitomised some of its values; as did her immediate family the Lees, who, as builders of roads and railways and makers of local opinion, embodied a vigorous period in the construction of national identity (David 1). In her use of visual textures within the novel Evans also followed in the Victorian spirit that sought to be 'generous', 'expansive' and always 'deeply entertaining' (David 2).

Although her novels were written and situated in the geographically isolated region of South Otago, New Zealand, Evans still participated in the Victorian novel's evolution and its debates concerning 'ideologies of gender, sexuality' and even the 'value of reading' itself (2). The light and entertaining tone of her work provided the vicarious flavour for an audience which was not highly literate, a milieu described by an 1887 critic as being uncritical, caring 'little for art for art's sake', yet a readership 'ever widening' in its scope and needs (Flint 20). Evans' publishing history with a reputable firm such as Sampson Low, at a time when publishers were reluctant to 'risk their capital', further reinforced her acumen as a writer of popular romantic fiction (20). It is now easy to overlook that Evans' work appeared at a time when purchasing fiction in hardback was expensive and even less likely to have been available during Oamaru's pioneer period (20).

A contemporary sideline to Evans' writing occurs also in her mention of colonial as a term of reference to be negotiated; its essential meaning needing somehow to be conveyed to a distant audience. In Over the Hills and Far Away Evans' mention of a story not 'too colonial in its language to be unintelligible' may have hinted at an underlying dilemma beyond the New Zealand exotic. For in stating her own case, which was the reality of being 'pioneer' yet also of England, Evans sought to preserve appearances by saying that she was 'civilised', still alive and well, in a place which at least in the moment could only have been another version of 'home'.

\section{LINKS}

'The North Otago Times', 1865-1874 $\underline{\text { Papers Past }}$ 
'Canons of a Genteel Society' In 'The North Otago Times', 1865-1874 Papers. Past.

'Sensation Novels' In 'The North Otago Times', 1865-1874 Papers Past

\section{Bibliography}

\section{BOOKS}

A Strange Friendship: A Story of New Zealand. London: Sampson Low, Marston, Low \& Searle; Dunedin: Reith \& Wilkie, 1874.

Guy Eversleigh. Oamaru Times. Oamaru, NZ: The North Otago Times, October/January1865-1866.

Over the Hills and Far Away: A Story of New Zealand. London: Sampson Low, Marston \& Searle; Dunedin: Reith \& Wilkie, 1874

Only a Woman's Hair (Three Short Novellas). London: Family Herald Press, 1903.

Our Nearest Neighbour. London: Family Herald Press, 1900.

Poetic Gems of Sacred Thought. Oamaru: J.H. Cunningham and Son, 1917.

\section{REFERENCES}

Collins, W. The Woman in White. London: Dent, 1959.

David, L. 'Sensation and the Fantastic in the Victorian Novel'. In The Cambridge Companion to the Victorian Novel. United Kingdom: Cambridge University Press, 2001.

David, D. (ed) The Cambridge Companion to the Victorian Novel. United Kingdom: Cambridge University Press, 2001.

Evans Charlotte (Lees) 1842-1882. Literary papers ATL MS 4426. Alexander Turnbull Library, Wellington, New Zealand.

Evans, Peter. Papers relating to the Evans, Lees and Grant Families, ATL MS 0328. Alexander Turnbull Library, Wellington, New Zealand. 
Fragments of Poetry and Prose. Bauld, J. The Story of Three Closely Linked New Zealand Colonial Families, Evans, Lees, Ogilvie-Grant, ATL MS 13/19/1, Alexander Turnbull Library, Wellington, New Zealand.

Moffat, K E. The Puritan Paradox: The Puritan Legacy in the Intellectual, Cultural and Social Life of New Zealand, Focusing Primarily on the Works of Novelists Writing between 1862 and 1940. Thesis Ph.D. (Victoria University of Wellington), 33.

Skillbeck, C. Jottings of a Gentleman. Ashburton, Victoria Australia: MonoUnlimited, 2007.

Stafford, J. and Williams, P. Maoriland: New Zealand Literature 1872-1914. Scott, M. (ed) Victoria University Press, Wellington, 2006.

Sturm, T. (ed) The Oxford History of New Zealand Literature in English. Auckland, N.Z: Oxford University Press, 1991. 